\title{
Pathogenic Assay of Probiotic Bacteria Producing Proteolytic Enzymes as Bioremediation Bacteria Against Vannamei Shrimp Larvae (Litopenaeus vannamei)
}

\author{
Wilis Ari Setyati ${ }^{1 *}$, Muhammad Zainuddin ${ }^{2}$ and Person Pesona Renta ${ }^{3}$ \\ ${ }^{1}$ Marine Science Department, Faculty of Fisheries and Marine Science, Diponegoro University \\ Jl. Prof. Soedarto, Tembalang, Semarang, Indonesia 50275 \\ ${ }^{2}$ Aquaculture Study Program, Faculty of Science and Technology, Nahdlatul Ulama Islamic University \\ Jl. Taman Siswa, Tahunan, Jepara, Indonesia 59427 \\ ${ }^{3}$ Marine Science Study Program, Faculty of Agriculture, University of Bengkulu \\ Jl. W.R. Supratman, Kandang Limun, Muara Bangka Hulu, Bengkulu, Indonesia 38371 \\ Email: wilisarisetyati@yahoo.co.id
}

\begin{abstract}
Application of bacteria in bioremediation of shrimp culture ponds is one of the methods used to clean internal pollutants. This study aimed to evaluate the pathogenicity of extracellular proteolytic enzyme produced by the probiotic bacteria as bioremediation bacteria on vannamei shrimp larvae culture. There were five probiotic bacteria, which were successfully isolated from the sediments served as substrate in mangrove area. The isolated bacteria were coded in number as 13, 19, 30, 33, and 36. Pathogenic bacteria Vibrio harveyi was used as positive control. Pathogenic assay was carried out in two different bacterial concentrations, i.e. $10^{8}$ and $10^{6}$ cells. $\mathrm{mL}^{-1}$. The results showed that the lowest survival rate (SR) of shrimp larvae in positive control V. harveyi was 53 and 65\%. Whereas isolates with the highest SR value (100\%) were obtained from bacteria coded as 13 and 30. Isolates no. 19, 33 and 36 had SR of more than 90\%. Total plate count (TPC) data showed that the bacteria increased significantly at the end of the study with an average increase value of $24 \%$. The smallest TPC value was shown by bacterial isolate no. 19, while the largest was obtained from the isolate no. 13. These results suggest that all probiotic bacteria were not pathogenic to the vannamei shrimp larvae.
\end{abstract}

Keywords: aquaculture, shrimp, bioremediation, pathogenesis, vibrio.

\section{Introduction}

Marine and brackish aquaculture produced large amounts of organic waste that are released into the surrounding environment. Most of the organic wastes come from the remaining of feed (uneaten food), and/or feces (Qian et al., 2001; Holmer et al., 2007). Organic waste further stimulates bacterial activity, which decline dissolved oxygen. Due to limited oxygen supply, the aerobic decomposition process shifts to the anaerobic decomposition.

Mugnier et al. (2007) reported that a synergistic interaction between the compounds of anaerobic metabolism especially ammonia with anaerobic environmental conditions impact the physiology of shrimp Litopenaeus stylirostris. Therefore, it is necessary to remove the accumulated organic materials in sediment ponds using bioremediation methods. Bioremediation process is based on the activity of facultative anaerobic microorganisms, such as bacteria that are active in the process of degradation in aerobic and anaerobic conditions.

In addition to bad environmental factors due to accumulation of organic wastes generated by cultivated organisms, problems encountered in the development of shrimp farming are factors of disease (Smith and Davey, 1993). Disease is primarily determined by the presence of pathogenic bacteria in the environment. Therefore, a strategy to control the presence of pathogenic bacteria is crucial and it is most effective through biocontrol.

Bioremediation and biocontrol are considered as an effective integrated strategy to maintain the sanitation of ponds. For that reason, the technological development of bioremediation and biocontrol is important to perform in order to improve the effectiveness and the efficiency of aquaculture activities in the future. Bioremediation and biocontrol agents are commonly known as probiotics. 
Probiotics are microbial cells culture product applied to clean the environment from contamination material (the decomposition of organic matter), to suppress the pathogenic population (mechanism antagonist) and to improve the digestibility of food (Moriarty, 1999). Therefore, probiotic becomes an alternative solution in an integrated disease control program (environmental aspect).

The application of probiotic, according to Kamiso (2004), is one of the disease control measures that gives promising results together with the shrimp fry screening activities, the usage of vaccines, immunostimulant and healthy cultivation patterns (good management practices). One of the probiotics is a consortium of bacteria antagonistic against pathogens in the pond ecosystem. This consortium has a mutual non-antagonistic and non pathogenic. Therefore this study was carried out to evaluate the pathogenicity of bacteria producing proteolytic enzymes isolated from sediments of mangrove as candidate of probiotics towards vannamei shrimp larvae L. vannamei.

\section{Materials and Methods}

Research was conducted by experimental Laboratory at MKHA laboratory, Center for Development of Brackish Water Aquaculture (BBPBAP) - Jepara regency. The research consisted of three phases: bacterial culture, preparation of shrimp and pathogenic assay. Culture of bacterial isolates encoded in numbers (no.) 13, 19, 30, 33 and 36 were grown on Zobell 2216 E broth media enriched with $2 \%$ of glucose and $0.05 \%$ of ammonium nitrate. Larvae of vannamei $L$. vannamei were acclimated with Artemia as live feed. Bacterial isolates no. 13, 19, 30, 33, 36 and the positive control bacteria Vibrio harveyi were evaluated for their pathogenic activity against the larvae of $L$. vannamei. Bacterial suspensions tested were prepared in two concentrations, i.e. $10^{8}$ cells. $\mathrm{mL}^{-1}$ and $10^{6}$ cells. $\mathrm{mL}^{-1}$. This study used autoclave, orbital shaker, centrifuge, micropipette, Spectrophotometer UV / Vis (Beckman), colony Quebec, tank aquarium size of $70 \times 60 \times 30 \mathrm{~cm}$, glass jar $3 \mathrm{~L}$, tank heater, aeration systems, and Water quality Checker.

\section{Isolates rejuvenation}

Pure culture media was stored and was rejuvenated in Zobell $2216 \mathrm{E}$ agar. Bacterial colonies were scratched with quadrant method at 2216 E Zobell media agar, were incubated for 24 hours at $35^{\circ} \mathrm{C}$ and were left to agitate in $150 \mathrm{rpm}$.

\section{Culture refreshment}

Culture refreshment was performed by taking $5 \mathrm{~mL}$ of culture solutions from each isolates no. 13, $19,30,33$ and 36. Later, they were put into $20 \mathrm{~mL}$ of Zobell media $2216 \mathrm{E}$ broth enriched with $2 \%$ of glucose and $0.05 \%$ of ammonium nitrate. Bacterial suspension was homogenized and was incubated for 24 hours at $35^{\circ} \mathrm{C}$ in $150 \mathrm{rpm}$.

\section{Culture scale up}

The scaling up of the bacterial culture was done by using $500 \mathrm{~mL}$ of media on the $1000 \mathrm{~mL}$ of erlenmeyer. The culture media was Zobell $2216 \mathrm{E}$ broth enriched with $2 \%$ of glucose and $0.05 \%$ of ammonium nitrate. A volume of $1 \%(\mathrm{v} / \mathrm{v})$ of inoculants at OD 0.01 on $A 600$ was added to the culture media. Further, it was incubated at $35{ }^{\circ} \mathrm{C}$, 30 ppt, in rpm for 24 hours.

\section{Bacteria turbidity measurements}

The dissolved oxygen (DO) determination was done by methods of Center for Development of Brackish Water Aquaculture (BBPBAP) Jepara by minor modification. Bacterial solution of $500 \mathrm{~mL}$ was centrifuged at $3000 \mathrm{rpm}$ for 10 minutes. Supernatants were discharged, while the pellets were washed and were dissolved with $100 \mathrm{~mL}$ of PBS solution followed by homogenization using vortex. Bacteria turbidity was read at $600 \mathrm{~nm}$.

\section{Shrimp preparation}

The shrimp larvae vanamei at post-larval stage (PL) 20 was used in this study. The fry/larvae were acclimatized for 3 days in the $100 \times 100 \times 30$ $\mathrm{cm}$ tank aquarium equipped with shelter as a place of refuge. In addition, the walls of the tank were covered by black plastic to avoid stress on the shrimps. A net was also added on top of the tank to prevent the shrimps jumping out of the tank. The larvae of $L$. vannamei were fed with Artemia concentrated at 3-5 ind. $\mathrm{mL}^{-1}$ four times a day. The feeding period was at 07:00, 11:00, 15:00, and 19:00 of local time. Management of water quality was conducted by syphon and the water was changed every morning by replacing $10 \%$ of total volume.

\section{Tank preparation and pathogenicity assay media}

Aquarium with the dimension of $70 \times 60 \times 30 \mathrm{~cm}$ and glass jar of $3 \mathrm{~L}$ were prepared by washing them detergent and were left to dry. After they were dry, they were disinfected by 100 ppm chlorine for 24 hours. Disinfected jars were filled with $2 \mathrm{~L}$ sterile seawater each, were put into the aquarium previously prepared with $6 \mathrm{~L}$ sterile seawater and a heater. 
Larvae of L. vannamei were cultured in sterile seawater. Sterile seawater was prepared by adding chlorine $30 \mathrm{ppm}$ to the non-sterile seawater followed by neutralization using Na-thiosulfate 15 ppm. Level of chlorine in sterilized seawater was regularly evaluated using Chlorine test.

\section{Pathogenic assay of probiotics}

Suspension of candidate probiotics was poured into the sterile media filled with larvae of $L$. vannamei to reach the final density of $10^{6}$ and $10^{8}$ CFU. $\mathrm{mL}^{-1}$. Experiments were carried out in two replicates with the positive control of $V$. harveyi bacteria. Larvae of $L$. vannamei with the density 10 ind. $\mathrm{mL}^{-1}$ were kept in a jar loaded with $2 \mathrm{~L}$ of sterile seawater and were fed with Artemia (3-5 ind. $\mathrm{mL}^{-1}$ ). Pathogenicity of probiotics through larval mortality was observed during 5 days of culture. Survival rate (SR) of shrimp larvae was determined and was compared with the positive control based on the following formula (Effendi, 2000):

\section{Bacteria colonies calculation}

The abundance of bacteria was determined using spread plate method. The sample was diluted in a series of dilution, such as $10^{-1}, 10^{-2}, 10^{-3}$, and so on, then was poured into a Petri dish, was incubated for 24 hours, and was counted. Bacterial colonies calculation was carried out by counting the number of bacterial colonies using a simple colony counter between 30 to 300 colonies on calculating tool Quebec colony counter machine by Collins et al., 2001.

Bacterial colonies were expressed in colonyforming units (CFU). $\mathrm{mL}^{-1}$ or as a viable count. $\mathrm{mL}^{-1}$. If the colonies in Petri dishes were more than 300 colonies, then the calculation could use the quadrant division, for example, one-quarter or oneeighth division calculation area (Mclntosh et al., 2001).

\section{Water quality}

Measurement of several water quality parameters including DO, temperature, salinity and $\mathrm{pH}$ were based on in-situ analysis using water quality checker. The water quality of larvae shrimp culture media was observed every day during the experiment.

\section{Data analysis}

Survival Rate (SR) of $L$. vannamei larvae was analyzed using the one way and two way analysis of variance (ANOVA) followed by post-hoc Tukey test ( $p$ $=0.05$ ) for a significant difference. As for the TPC, the data were analyzed using one way and three way ANOVA followed by post-hoc Tukey test $(P=0.05)$ for a significant difference. The data of water quality were analyzed by means of descriptive tabulation based on minimal and maximal interval

\section{Results and Discussion}

Pathogenicity assay was performed in this study was meant to evaluate whether the isolated probionts used in this study were pathogenic to the larvae of $L$. vannamei. It is important to consider the pathogenicity of probionts prior to application since it becomes the primary requirements of probiotics (Gomez-Gil \& Roque, 1998).

Figure 1 showed that isolates probiotics no. 13 and 30 at $10^{6}$ and $10^{8}$ CFU. L $^{-1}$ had the same SR (survival rate) value, which was $100 \%$. On the other hand, isolates no. 19 and 36 at $10^{6}$ CFU. $\mathrm{mL}^{-1}$ had the same SR value, $95 \%$, while the value of SR at $10^{8}$ CFU.mL-1 was $90 \%$. Isolate 33 at concentration $10^{6}$ and $10^{8}$ had SR value by $93 \%$ and $90 \%$. The SR of larvae L. vannamei introduced with pathogenic bacteria $V$. harveyi at $10^{6}$ and $10^{8}$ CFU.mL-1 were quite low with $65 \%$ and $53 \%$, respectively. Based on the SR data above, the isolates probiotics encoded 13, 19, 30, 33 and 36 were not pathogenic because the SR reached more than 90\%. Amin \& Hendrajat (2008) reported that the application of probiotics in shrimp vannamei live media generates SR 92-94\%, implied that the use of probiotics in shrimp farming can provide a significant effect to the survival rate of the shrimps.

According to Irianto (2003), Bacillus sp used as probiotic bacteria did not affect the survival rate of shrimp larvae. Verschuere et al. (2000) stated that the addition of probiotic bacteria to the media could contribute to the maintenance of shrimp larvae in the digestive system as well as biocontrol. In the positive control, larvae of $L$. vannamei introduced to $V$. harveyi, the survival rate dropped to nearly $50 \%$. It indicates that the pathogenicity of $V$. harveyi managed to decrease the population of $L$. vannamei larvae to $50 \%$. This result is in accordance with that of Lavilla-Pitogo et al. (1998) implying that high mortality in shrimp culture often occurs during the post-larvae, juvenile and young shrimp. Normally, the mortality of shrimp happens $48 \mathrm{~h}$ after the infection caused by $V$. harveyi. $V$. harveyi is an opportunistic pathogen, thus, the pathogenicity of this bacteria increases if the amount of bacteria is high and the immunity of the host weakens (Wood, 1974).

Results of two-way ANOVA analysis of SR data showed that difference treatment towards the isolates could influence significantly the SR values 
$(P<0.05)$. SR of positive control was the lowest and was significantly different $(P<0.05)$ with the bacterial isolates of candidate probiotic. Isolates no. 33, 36 and 19 had SR values that were not significantly different $(P<0.05)$. But these isolates differed significantly $(P<0.05)$ against isolates no. 13 and 30 . Isolates no. 13 and 30 had values of SR that were not significantly different $(P<0.05)$. It seems that different concentrations of bacterial suspension affected significantly the SR values $(P<0.05)$. Bacterial suspension of $10^{8}$ cells. $\mathrm{mL}^{-1}$ had smaller significantly different of SR values $(P<0.05)$ to the treatment of concentration of $10^{6}$ cells. $\mathrm{mL}^{-1}$.

Table 1. One Way Anova of SR Value based on the Pathogenicity Assay of Probiotics in Different Concentration.

\begin{tabular}{ccc}
\hline \multirow{2}{*}{ Treatments } & \multicolumn{2}{c}{ Bacteria Concentrations } \\
\cline { 2 - 3 } & $10^{6}$ & $10^{8}$ \\
\hline Isolate 13 & $100 \pm 0,0 \mathrm{~b}$ & $100 \pm 0,0^{\mathrm{c}}$ \\
Isolate 19 & $95 \pm 7,1^{\mathrm{b}}$ & $90 \pm 3,5 \mathrm{~b}$ \\
Isolate 30 & $100 \pm 3,5^{\mathrm{b}}$ & $100 \pm 0,0 \mathrm{c}$ \\
Isolate 33 & $93 \pm 0,0 \mathrm{~b}$ & $90 \pm 0,0 \mathrm{~b}$ \\
Isolate 36 & $95 \pm 0,0 \mathrm{~b}$ & $90 \pm 0,0 \mathrm{~b}$ \\
V harveyi & $65 \pm 0,0 \mathrm{a}$ & $53 \pm 0,0 \mathrm{a}$ \\
\hline
\end{tabular}

Description: Data are mean \pm standard deviation; Different italic letters on the back of data on the same column are significantly different $(P<0.05)$; the concentration of bacteria in units of CFU. $\mathrm{mL}^{-1}$.

Results of one-way ANOVA from the SR data as presented in Table 1 indicated that the different concentrations of bacteria isolated from the sediment of mangrove significantly influenced SR value $(P<0.05)$. Bacterial suspension of $10^{6}$ CFU. $\mathrm{mL}^{-}$ 1 showed to influence the survival rate significantly $(P<0.05)$. Positive control had the lowest SR value and significantly different $(P<0.05)$ from the other 5 bacterial isolates candidate as probiotic. However, the SR values of isolates between no. 13, 19, 30, 33 , and 36 did not show a significant different $(P<0.05)$

Different type of bacterial isolates at concentrations of $10^{8} \quad$ CFU.mL $L^{-1}$ influenced significantly the SR values $(P<0.05)$. Positive control had the lowest $S R$ value and showed significant different $(P<0.05)$ with the other 5 bacterial isolate. Isolates no. 19, 33 and 36 had values of SR, which were not significantly different to each other $(P<0.05)$. In addition, isolates no. 13 and 30 had values of SR which were not significantly different $(P<0.05)$. However, a significantly different $(P<0.05)$ was shown by isolates no. 13 and 30 .

Figure 2 showed that generally the bacteria had an increasing density in the end of the research. Isolates no13 concentrated at $10^{8}$ and $10^{6} \mathrm{CFU} \cdot \mathrm{mL}^{-1}$ increased in the density of bacteria, by $55 \%$ and $88 \%$. The density of isolates no. 19, 30, 33 and 36 at $10^{8}$ and $10^{6}$ CFU.mL-1 were 4 and $22 \%, 42$ and $69 \%, 23$ and 27\%, 21 and 43\%, respectively. Meanwhile, the density of $V$. harveyi was 1 and 33\%.

The results of three way ANOVA analysis of TPC log data presented indicated that isolates no. 19 had the lowest TPC log value, while no. 13 had the highest TPC log value. V. harvayi, and isolate of the probiotic no. $19,33,36,30$ and 13 had great TPC log value and showed a significant differenceone to another $(P<0.05)$. Furthermore, different bacterial suspension $\left(10^{6}\right.$ and $10^{8}$ CFU.mL1) affected the TPC significantly $(P<0.05)$, in which the TPC of bacterial suspension at $10^{8}$ CFU. $\mathrm{mL}^{-1}$ was higher then the $10^{6}$ CFU.mL-1. Based on the observation time, the initial log TPC was significantly

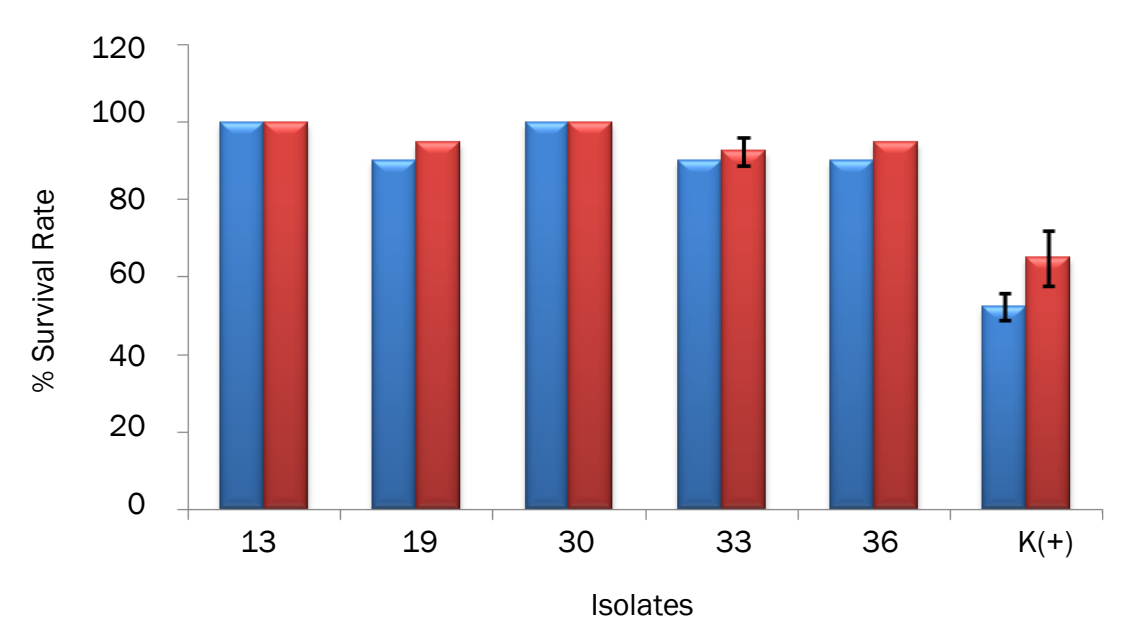

Figure 1. Percentage of survival rates in pathogenic assay from difference probiotics Note. $\square=10^{8}, \square=10^{6}$ 


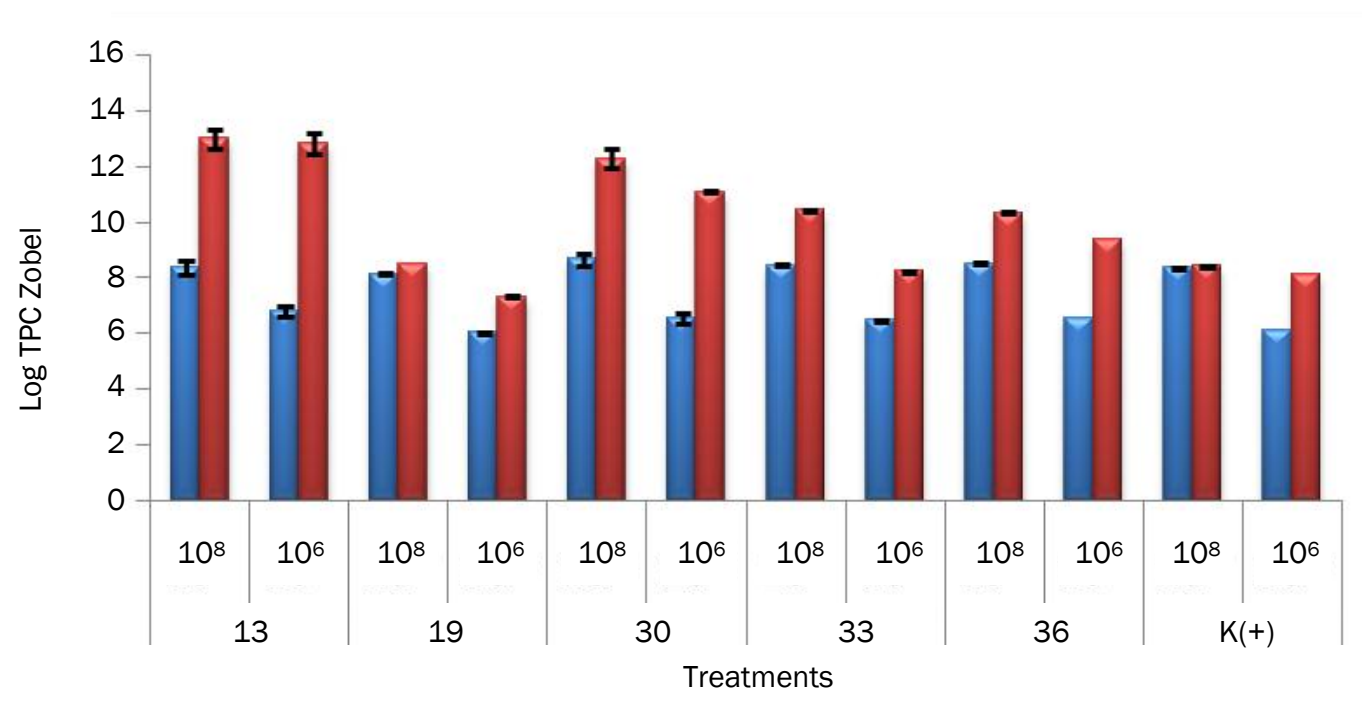

Figure 2. Log TPC At Pathogenicity Assay from Different Isolates of Probiotic Note. $\square=$ initial, $\square=$ end

Table 2. One Way Anova of TPC Log Value In Pathogenicity Assay of Different Probiotics Isolates.

\begin{tabular}{ccc}
\hline \multirow{2}{*}{ Treatments } & \multicolumn{2}{c}{ Bacteria Concentrations } \\
\cline { 2 - 3 } & $10^{6}$ & $10^{8}$ \\
\hline Isolate 13 & $12,851 \pm 0,031^{\mathrm{e}}$ & $13,005 \pm 0,347^{\mathrm{c}}$ \\
Isolate 19 & $7,352 \pm 0,023 \mathrm{a}$ & $8,518 \pm 0,023 \mathrm{a}$ \\
Isolate 30 & $11,117 \pm 0,023^{\mathrm{d}}$ & $12,297 \pm 0,029 \mathrm{c}$ \\
Isolate 33 & $8,243 \pm 0,026 \mathrm{~b}$ & $10,454 \pm 0,029 \mathrm{~b}$ \\
Isolate 36 & $9,390 \pm 0,020 \mathrm{c}$ & $10,352 \pm 0,024 \mathrm{~b}$ \\
V harveyi & $8,146 \pm 0,363^{\mathrm{b}}$ & $8,431 \pm 0,367 \mathrm{a}$
\end{tabular}

Description: Data are mean \pm standard deviation; Different italic letters on the back of data on the same column are significantly different $(P<0.05)$; the concentration of bacteria in units of CFU.m ${ }^{-1}$.

lower $(P<0.05)$ than the final log TPC, i.e. after incubation.

Table 2 displayed the significant difference of bacteria concentrations based on the TPC log in probiotics isolates after incubation $(p<0.05)$. Bacterial suspension at $10^{6} \mathrm{CFU} / \mathrm{mL}$ showed that isolates no. 19 had the lowest TPC log value and lower significantly different $(p<0.05)$ against isolates 13,30 and 36 . Isolate no. 33 and $V$. harveyi was not significantly different $(p<0.05)$. Isolates 36 and 30 were significantly lower to each other $(p<0.05)$.

Treatment of concentration $10^{6}$ CFU.mL-1 indicated that $V$. harveyi had the lowest TPC log value and did not differ significantly $(P<0.05)$ against isolates no. 19. Isolate no. 36 and 33 were not significantly different $(p<0.05)$. Isolates no. 13 and 30 were also not significantly different $(P<0.05)$.

Water quality of the media had an important role in supporting the shrimp life. The pathogenicity. DO, temperature, salinity and $\mathrm{pH}$ were the parameters observed during this study. Results of these observations are presented in Table 3. The water quality of shrimp culture media had enormous influence on the growth, SR, molting frequency, as well as the population of pathogenic bacteria. DO, temperature, salinity and $\mathrm{pH}$ of the media used to culture the shrimp larvae ranged from 5.40 to 6.28 ppm, 27.50 to $32.50^{\circ} \mathrm{C}, 25.00$ to $35.00 \%$ and 7.00 to 8.46 , respectively.

The optimal conditions for shrimp cultivation as mentioned by Anonymous (2003), are DO> 4 mg. $\mathrm{L}^{-1}$ (tolerance of at least $0.8 \mathrm{mg} . \mathrm{L}^{-1}$ ), temperature of $28-31^{\circ} \mathrm{C}$ (tolerance to $16-36^{\circ} \mathrm{C}$ ), salinity $10-35$ ppt (tolerance to $50 \mathrm{ppt}$ ), and $\mathrm{pH}$ of 7.00 to 8.70 . In this study, the water quality of the media used was still in the favorable range for the shrimps. Wedemeyer (1977) stated that a favorable environmental condition during the shrimp cultivation activity would increase resistance to disease; while poor environmental conditions leading to stress and might provoke the susceptibility of shrimps to disease.

Table 3. Parameter Water Quality In Situ

\begin{tabular}{cc}
\hline Parameters & Data range \\
\hline DO & $5,40-6,28 \mathrm{ppm}$ \\
Temperature & $27,50-32,50{ }^{\circ} \mathrm{C}$ \\
Salinity & $25,00-35,00 \%$ \\
$\mathrm{pH}$ & $7,00-8,46$ \\
\hline
\end{tabular}




\section{Conclusions}

Positive control showed lower survival rate compared to the other probiotics isolate, with SR value at 53 and $65 \%$. Whereas isolates with the highest values of SR were isolates no. 13 and 30 with $100 \%$ of SR. Isolates no.19, 33 and 36 had value of SR inferior than $90 \%$. TPC log data indicated that the bacteria had increased significantly in the end of the research with an average value of $24 \%$. The smallest TPC log value in end of the research was isolates no.19, whereas the largest was isolates no.13. The results showed that probiotic bacteria no. $13,19,30,33$ and 36 were not pathogenic to the larvae of $L$. vannamei.

\section{References}

Amin, M. \& Hendrajat, E.A. 2008. Pengaruh konsentrasi probiotik terhadap pertumbuhan dan sintasan udang vaname (Litopenaeus vannamei) pada bak terkontrol. Prosiding Seminar dan Konferensi Nasional 2008. Bidang Budidaya Perairan. Fakultas Perikanan dan IImu Kelautan Universitas Brawijaya, Malang, 103-106 pp

Anonymous. 2003. Litopenaeus vannamei Sebagai Alternative Budidaya Udang Saat Ini. PT. Central Proteinprima (Charoen Pokphand Group) Surabaya, $16 \mathrm{hlm}$.

Effendi, H. 2000. Telaah Kualitas Air : Bagi Pengelolaan Sumberdaya Dan Lingkungan Perairan. Gramedia : Jakarta

Gomez-Gil, B. \& Roque, A. 1998. Selection of Probiotic Bacteria for Use in Aquaculture (Abstract). Proceedings to the Special Session on Shrimp Biotechnology. $5^{\text {th }}$ Asian Fisheries Forum. Chiang Mai, Thailand 11-14 November 1998.

Holmer, M., Marba, N., Diaz-Almela, E., Duarte, C.M, Tsapakis. M. \& Danovaro, R. 2007. Sedimentation of Organic Matter from Fish Farms In Oligotrophic Mediterranean Assessed through bulk \& stable isotope (d13C \& d15N) analyses. Aquaculture. 262:268-280.

Irianto, A., 2003. Probiotik Akuakultur. Cetakan Pertama. Gadjah Mada University Press. Yogyakarta.

Kamiso, 2004. Status Penyakit Ikan dan Pengendaliannya. Proc. Seminar Penyakit Ikan dan Udang IV, Unsoed, Purwokerto.
Lavilla-Pitogo, C.R. \& De La Pena, L.D. 1998. Mortalities of pond-cultured Juvenile Shrimp, Penaeus monodon Associated With Dominance of Luminescent Vibrios in the Rearing Environment. Aquaculture. 164:337-349. doi: doi : 10.1016/S0044-8486(98)00198-7

Mclntosh, D., Fitzsimmons, K., Aguilar, J. \& Collins, C. 2001. Shrimp Aquaculture \& Olive ProductionSustainable Integration. Report. University of Arizona, Environmental Research Lab.

Moriarty, D.J.W. 1999. Disease Control in Shrimp Aquaculture with Probiotic Bacteria, In: Proceedings of the $8^{\text {th }}$ International Symposium on Microbial Ecology. Bell, C.R., Brylinsky, M., Johnson-Green, P. (Eds.) Atlantic Canada Society for Microbial Ecology. Halifax, Canada, 1999.

Mugnier, C., Zipper, E., Goartant, C. \& Lemonnier, H. 2007. Combined effect of exposure to ammonia and hypoxia on the blue shrimp Litopenaeus stylirostris survival and physiological response in relation to molt stage. Aquaculture. 274:398-40. doi: 10.1016/j.aqua culture.2007.11.033

Qian, P.Y., Wu, M.C.S. \& Ni, I.H. 2001. Comparison of nutrients release among some maricultured animals. Aquaculture. 200:305-316. doi: 10. 1016/S0044-8486(00)00604-9

Smith, D. \& Davey, S. 1993. Evidence for The Competitive Exclusion of Aeromonas salmenicida From Fish With Stress-Inducible Furrunculosis by A Fluorescent Pseudomonas. J. Fish Diseases. 16: 521-524. doi: 10.1111/j.1365-2761.1993.tb00888.x

Verschuere, L., Rombuat, G., Sorgeloos, P. \& Verstraete, W. 2002. Probiotic Bacterial as Biological Control Agents In Aquaculture. Microbial mol. Biol. Rev., 64(4): 655-671.

Wedemeyer, G.A. \& Yasutake, W.T. 1977. Clinical Methods for assessment of Effect on Environmental Stress on Fish Health. Technical Papers of the U.S. Fish and Wildlife Service. U.S Department of the Interior. Fish and Wildlife Service. Technical Paper 89, 18.pp

Wood, J.W. 1974. Diseases of Pacific Salmon Their Prevention and Treatment. Second ed., State of Washington, Department. of Fish, Olympia, Washington. 81pp. 